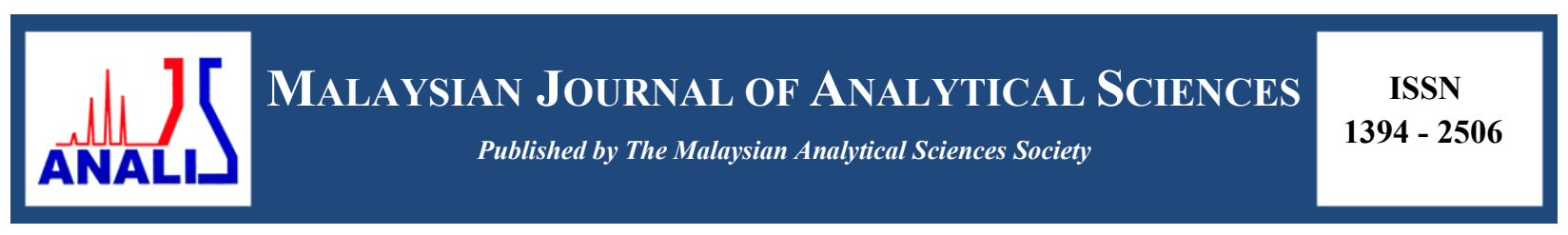

\title{
EVALUATION OF DOSE SENSITIVITY RESPONSE VIA OPTICAL CHARACTERISTICS FOR CRESOL RED-DYED POLYHYDROXYETHYLMETHACRYLATE GEL (PHEMAG)
}

\author{
(Penilaian Respons Kepekaan Dos Melalui Ciri Optikal Bagi Kresol Merah-Dicelup \\ Polihidrosietilmetakrilik Gel (PHEMAG)) \\ Nur Sha'adah Zainuddin ${ }^{1 *}$, Fairuzdzah Ahmad Lothfy ${ }^{1}$, Hartini Ahmad Rafaie ${ }^{1}$, Mazlini Mazlan², \\ Iskandar Shahrim Mustafa ${ }^{3}$, Azhar Abdul Rahman $^{3}$ \\ ${ }^{1}$ Faculty of Applied Sciences, \\ Universiti Teknologi MARA Pahang, 26400 Bandar Tun Abdul Razak Jengka, Pahang, Malaysia \\ ${ }^{2}$ Faculty of Applied Sciences, \\ Universiti Teknologi MARA Tapah, 35400 Tapah, Perak, Malaysia \\ ${ }^{3}$ School of Physics, \\ Universiti Sains Malaysia, 11800 Minden, Pinang, Malaysia \\ *Corresponding author: nsz@pahang.uitm.edu.my
}

Received: 4 December 2016; Accepted: 1 December 2017

\begin{abstract}
A new polymer gel blended with the acid base indicator of cresol red were prepared consisted of $4 \%, 5 \%$ and $6 \%$ of monomer (2-Hydroxyethyl Methacrylate; HEMA) in order to characterize the radiation induced changes known as cresol red Polyhydroxyethylmethacrylate Gel (PHEMAG). Cresol red-dyed PHEMAG were prepared consisted of gelatin, deionized water, HEMA, cresol red sodium salt stock solution and ascorbic acid. The polymerization Cresol red-PHEMAG was studied with 6 MV photon beam rates $300 \mathrm{~Gy} / \mathrm{min}$ which received doses up to $40 \mathrm{~Gy}$ for the reveletion sensitivity as a function of absorbed dose based on the physical properties by using UV-Vis spectroscopy. It is indicated that 4\% of HEMA exhibited a greater sensitivity of the polymer gel dosimeter based on a mathematical model of the fitting equation of the dose response curve. The value of $\boldsymbol{D}_{o}$ (sensitivity parameter) for $4 \%$ of HEMA is the lowest about 42.373 Gy. The lower value of $\boldsymbol{D}_{o}$ would cause the higher radiosensitive of the matter which was actively reacted at the time of exposure.
\end{abstract}

Keywords: absorbed dose, cresol red, photon beam, polymer gel

\begin{abstract}
Abstrak
Gel polimer baru dicampur dengan penunjuk asas asid kresol merah telah disediakan yang terdiri daripada 4\%, 5\% dan $6 \%$ daripada monomer (2- hidrosietilmetakrilik; HEMA) untuk mencirikan radiasi mendorong perubahan yang dikenali sebagai Kresol merah-dicelup Polihidrosietilmetakrilik Gel (PHEMAG). Kresol merah - dicelup PHEMAG telah dihasilkan terdiri daripada gelatin, air nyah ion, HEMA, stok larutan kresol merah natrium garam dan asid askobik. Pempolimeran kresol merah PHEMAG telah dikaji dengan pancaran foton $6 \mathrm{MV}$ pada kadar yang berterusan $300 \mathrm{~Gy} / \mathrm{min}$ yang menerima dos sehingga 40 Gy untuk mendedahkan kepekaan sebagai fungsi dos terserap berdasarkan sifat-sifat fizikal dengan menggunakan spektroskopi UV-Vis. Ia menunjukkan bahawa 4\% daripada HEMA menghasilkan kepekaan polimer gel dosimeter yang lebih tinggi berdasarkan model persamaan matematik sesuai tindak balas dos keluk. Nilai $\boldsymbol{D}_{o}$ (parameter sensitiviti) untuk $4 \%$ daripada HEMA adalah yang paling rendah kira-kira 42.37 Gy. Nilai yang lebih rendah daripada $\boldsymbol{D}_{o}$ akan menyebabkan radiosensitif jisim yang bertindak balas secara aktif pada masa pendedahan.
\end{abstract}

Kata kunci: dos terserap, kresol merah, pancaran foton, gel polimer 


\title{
Nur Sha'adah et al: EVALUATION OF DOSE SENSITIVITY RESPONSE VIA OPTICAL CHARACTERISTICS FOR CRESOL RED-DYED POLYHYDROXYETHYLMETHACRYLATE GEL (PHEMAG)
}

\begin{abstract}
Introduction
Dosimeter is a device that would able to measure quantitatively such as absorbed dose, equivalent dose or other related radiation quantities. This variation of dosimeter is mostly required to exhibit an ideal dosimeter based on the energy deposited in term of absorbed dose for the detection limit from exceeding the dose required during the treatment either from radiology or industry modalities. Polymer gel dosimeter promises a great response of the absorbed dose in three dimensions that able to overcome the limitation of the common dosimeter such as absolute dosimeter and ionization chamber. These responses based on retaining of 3D spatial dose distribution mostly in the application of radiology and radiotherapy treatment $[1,2]$. Basically, the radiological treatment is mostly targeted on the carcinogenic tissue of the patient by considering the limitation of the surrounding tissue. The integrated of absorbed dose in 3D of polymer gel, raises great interest amongst the researcher in order to improve their accuracy, sensitivity, reproducibility and stability of the dosimeter. The first polymer gel created by Fricke and Morse in 1927 is according to the radiation-induced ferrosulphate solution until a further development with the addition of the monomer and then blend with the gel matrix. This revolution of the polymer gel dosimeter has been exposed by a different type of radiation modality that has either low or high energy, and characterizes absorbed dose in terms of physical, and structural characterization [3-5]. The solid polymer blends with the dyes that have a great response to transition of visual color and acts as a radiation-sensitive indicator that could be the prior requirement to ascertain the absorbed dose displayed once it is introduced to the ionizing radiation [6,7]. Thus by this concept of this solid polymer blend cresol red dye, it shows a great response of optical properties and optical transitions which leads to the use of the gelatins compared of the solid polymer as a gelling agent in order to maintain the polymer aggregated for the post irradiation. The main objective of this project was to fabricate and characterized the optical properties and dosimetric parameter of radiation-induced cresol red-dyed PHEMAG as a dosimeter according to the various of the concentration of monomer (HEMA). The high energy of photon beam that induced the color transition of cresol red-dyed PHEMAG was being measured quantitatively and qualitatively according to its $\mathrm{pH}$, visible absorption dose response and structural characterization.
\end{abstract}

\section{Stock solution of cresol red}

\section{Materials and Methods}

The stock solution of Cresol Red as an acid-base indicator is synthesised based on the formulation introduced by Ebraheem et al. [7] and was modified in terms of controlling its $\mathrm{pH}$ level in a basic form for cresol red-dyed PHEMAG before irradiated [6, 8]. A purple form of basic cresol red dye which is alkaline in the range of $\mathrm{pH}>8.8$ whereas in the acidic form in the range of $2.8<\mathrm{pH}<7.2$ [6]. For that purpose, $0.08 \mathrm{~g}$ of cresol red (product of $\mathrm{R} \& \mathrm{M}$ chemicals) was dissolved in $15 \mathrm{ml}$ of aqueous $\mathrm{NaOH}$ solution $([\mathrm{NaOH}]=1.0 \mathrm{~mol} / \mathrm{l})$ and completed its final volume with ethanol in $50 \mathrm{ml}$ volumetric flask. This stock solution was stirred for 5 minutes at room temperature to ensure a homogenous cresol red dye stock solution. This stock solution was stored in a refrigerator $\left(4{ }^{\circ} \mathrm{C}\right)$ overnight and covered withopaque ziplock bags prior to minimize the degradation of the the dye from direct sunlight since the dye is a photosensitizer [9].

\section{Synthesis of Cresol red-dyed Polyhydroxyethylmethacrylate( PHEMAG) gel dosimeter}

The PHEMAG gel dosimeter formulation, introduced by Rozlan et al. [10], was used as a foundation to study a new polymer gel dosimeter with a different concentration of monomer (HEMA) and doped with the cresol red dye. This new synthesis of polymer gel was named as Cresol red-dyed PHEMAG polymer gel dosimeter. Cresol red-dyed PHEMAG were prepared consisted of $8 \%(\mathrm{w} / \mathrm{w})$ gelatine (bovine skin, Type B, Sigma Chemical Co), $88 \%$ (w/w) of deionized water, $(4 \%, 5 \%$ and $6 \%(\mathrm{w} / \mathrm{w})$ of 2-Hydroxyethyl Methacrylate, HEMA $96 \%$ stabilized from ACROS Organics), $5 \mathrm{~mL}$ of cresol red sodium salt stock solution and $4 \mathrm{mM}$ of antioxidant (AA) (CalbioChem) under normal atmospheric conditions [11]. The antioxidant was used in order to inhibit free radical copolymerization reactions for normoxic polymer gel dosimeter $[12,13]$. The gelatine was dissolved with deionized water, allowed to swell and stirred with magnetic stirrer by heating up to $50^{\circ} \mathrm{C}$ in the water bath until a clear solution is shown. Then the gelatin solution was cooled down until reached it reach of $40^{\circ} \mathrm{C}$. An amount of $5 \mathrm{ml}$ cresol red sodium salt stock solution is added in the mixture. The mixture solution show the changes in colour from purple to red-orange which was correlated to its $\mathrm{pH}$ transition in basic form around $\mathrm{pH}>8$ [10]. Lastly, HEMA and AA were added and stirred at a room temperature for half an hour. Throughout the cooling process of the mixed solution, the beakers were covered 
with the aluminium foils and covered with the opaque wrapper in order to minimize the polymer gel from lightinduced polymerization.It was then filled into the $4 \mathrm{ml}$ cuvette and sealed with parafilm tape [9]. The gels were stored in a refrigerator $\left(4^{\mathrm{O}} \mathrm{C}\right)$ overnight in order to solidify the cresol red dye polymer gel for pre and post irradiation process.

\section{pH measurement and UV absorbance}

After the fabrication of the polymer gel (before stored in the freezer), the $\mathrm{pH}$ for each batch of cresol red-dyed PHEMAG in aqueous solution was measured by using a digital $\mathrm{pH}$ meter pen respectively. Before taking the measurement, the $\mathrm{pH}$ meter was calibrated by using a buffer solution of $\mathrm{pH} 7$ right after the electrode was rinsed with the distilled water. In addition, the UV-1800 Shimadzu spectrophotometer was used to analyze the absorption spectra of cresol red-dyed PHEMAG pre and post irradiated in the range of $200 \mathrm{~nm}$ and $800 \mathrm{~nm}$ by using the double beam photometric system and air as reference.

\section{Irradiation of cresol red-dyed PHEMAG}

All the samples were studied for their characteristics based on physical properties such absorption response curve and sensitivity according to the radiation-induced of the polymer gels. After solidify for overnight all the batches of the polymer gels were irradiated using Siemens Mevatron Linear Accelerator (LINAC) at Mount Miriam Cancer Hospital (MMCH) with parallel opposed $15 \mathrm{~cm} \times 15 \mathrm{~cm}$ beams. This was so that the uniform dose distribution between 25 Gy up to 40 Gy of accumulated dose could be received. Also, the unirradiated bathces were left as background reading. The Perspex slab $30 \mathrm{~cm}$ width $\times 30 \mathrm{~cm}$ length) with the total thickness around $1.2 \mathrm{~cm}$ is used as cuvettes holder. The cuvettes is placed in the middle of the separation distance of $10 \mathrm{~cm}$ of solid water phantom slabs. The source-surface distance (SSD) was set at $95 \mathrm{~cm}$ so that the samples were irradiated isocentrically at $5 \mathrm{~cm}$ depth from the surfaces of the phantom with equally weighted. Then, $4.4 \mathrm{~cm}$ of solid water phantoms were placed on top of the polymer gels to give adequate build-up of the region of irradiation dose. It also minimizes backscatter radiation for maximum absorbed dose once the photon beam interacts with the polymer gel $[5,14]$.

\section{Indicator basicity of Cresol red-dyed PHEMAG}

\section{Results and Discussion}

The mixture of the gelatine with water created the acidity of $\mathrm{pH} 5.5$, meanwhile a stock solution of cresol red with $\mathrm{pH} 13.10$ is made in high concentration of basicity with optimum molarity of $1.0 \mathrm{M} \mathrm{NaOH}$. The molarity of $\mathrm{NaOH}$ is crucial in order to control the final basicity of cresol red-dyed PHEMAG before irradiated based on the physical changes of color as shown in Figure 1. As illustrated in Figure 1, the colour variation of polymer gel and the $\mathrm{pH}$ value shows that the optimum molarity of $1.0 \mathrm{M} \mathrm{NaOH}$ is the most suitable concentration to be used during the fabrication process which acts as colour indicator. The $\mathrm{pH}$ value in Figure 1(a) is 7 whereas in Figure 1(b) is 8.9 that can be correlated to the color transition based on research work done by Susilawati in 2005 [15] as depicted in Figure 3(a).

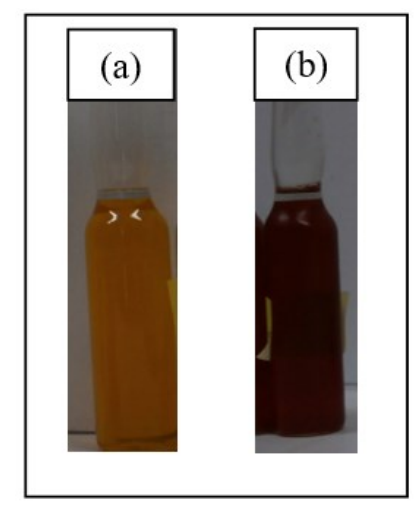

Figure 1. The physical changes of cresol red-dyed PHEMAG before irradiated (a) cresol red-dyed PHEMAG consist of $0.1 \mathrm{M}$ of $\mathrm{NaOH}$ and (b) cresol red-dyed PHEMAG consist of $1.0 \mathrm{M}$ of $\mathrm{NaOH}$ 


\section{Nur Sha'adah et al: EVALUATION OF DOSE SENSITIVITY RESPONSE VIA OPTICAL CHARACTERISTICS FOR CRESOL RED-DYED POLYHYDROXYETHYLMETHACRYLATE GEL (PHEMAG)}

\section{Visible absorption spectra}

The effect of ionizing radiation on cresol red-dyed PHEMAG was measured by using UV-Vis spectroscopy for the absorbance spectra corresponding to the absorbed dose 25 Gy up to 40 Gy respectively for $4 \%, 5 \%$ and $6 \%$ of HEMA as shown in Figure 2.

The maximum absorbance at wavelength $575 \mathrm{~nm}$ was chosen, and it is indicated that the dosimetric properties for the visual red orange color of the cresol red-dyed PHEMAG $[8,16]$. The $\mathrm{pH}$ value for pre-irradiation of cresol reddyed PHEMAG was around $8.33 \pm 0.15$ as the basic visual color of red-orange before it is changed into orange after irradiation. From the Figure 2 (c), $575 \mathrm{~nm}$ band showed a gradually increment as compared to Figure 2(a) and (b) which illustrate slight increament with the increased of the absorbed dose. It was mainly due to the radiolysis of water molecules of polymer gel. It also caused the slightly dissociations of cresol red dye into acidic but still in basic solution [16]. Indirectly, the free radicals that were formed reacted with the cresol red dye hence slightly contributed to the formation of $\mathrm{H}^{+}$in volume interest of cresol red-dyed PHEMAG. With the highest absorbed dose ( $40 \mathrm{~Gy}$ ), the absorption band increased at $575 \mathrm{~nm}$ due to the disorder defect in the amorphous nature in the polymer chain of PHEMAG. Hence, it induced more degradation and discoloration of cresol red-dyed PHEMAG. It attributed to the formation of acidic form in the reaction further with cresol red dye which changing the colour from red-orange towards orange as illustrated in Figure 3(b) [8].
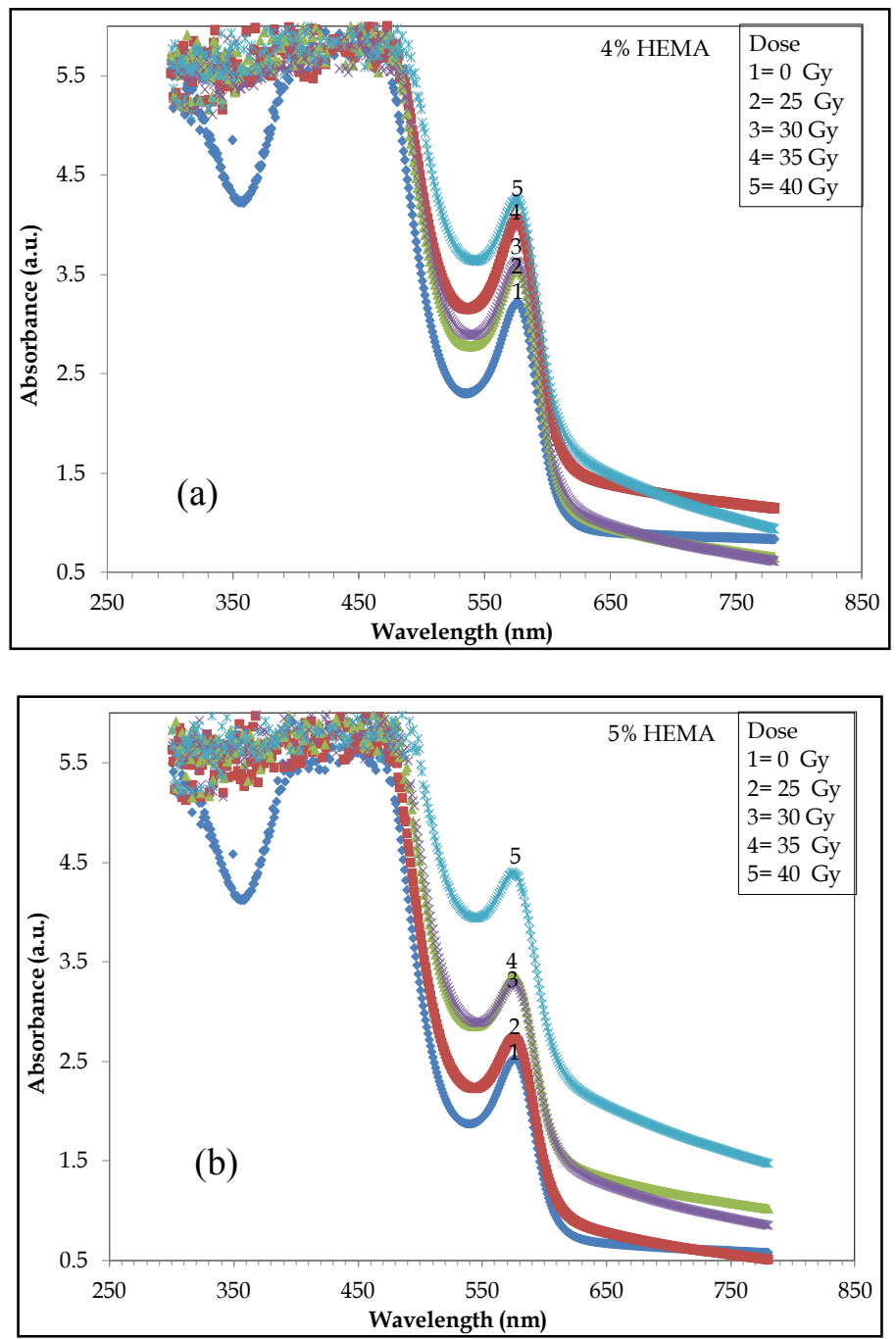


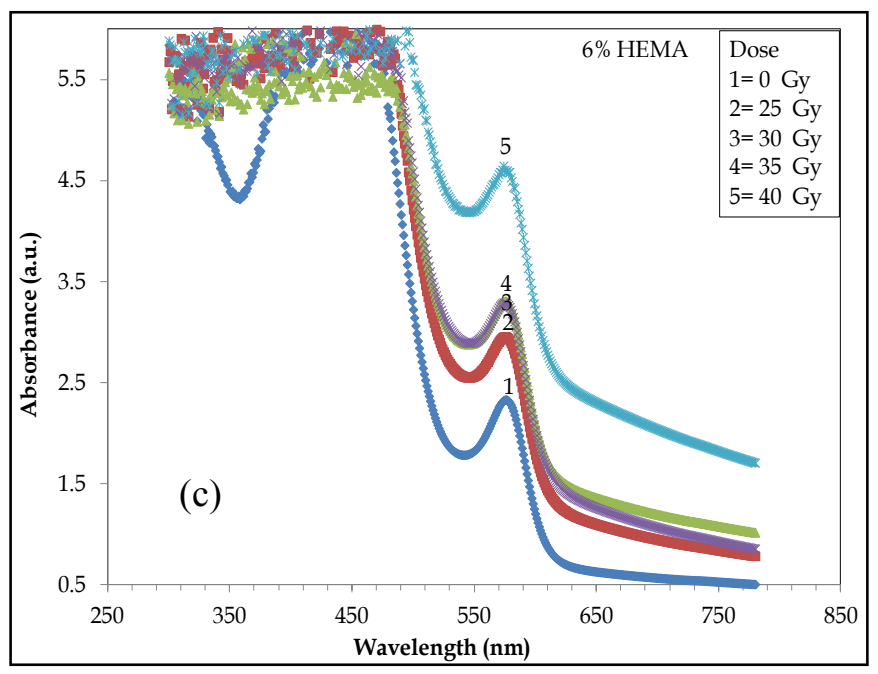

Figure 2. Absorption spectra of the cresol red-dyed PHEMAG pre and post irradiation for (a) $4 \%$ of HEMA, (b) $5 \%$ of HEMA and (c) $6 \%$ of HEMA

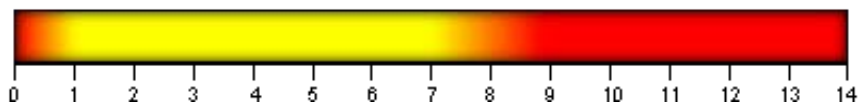

(a)
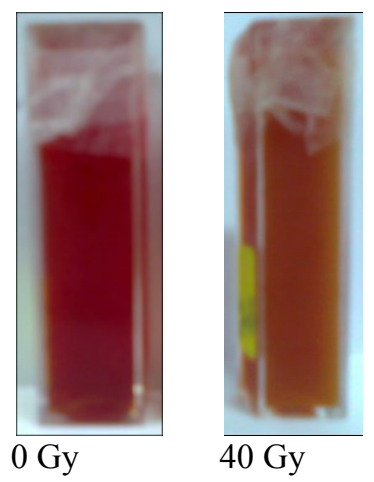

(b)

Figure 3. The visual color transition of (a) cresol red in basic solution, (b) cresol red-dyed PHEMAG for $4 \%$ HEMA

\section{Dose response curves}

Dose response is defined as the dose range over defined energy that is proportional to the amount of incident radiation [17]. The dose response curve of cresol red-dyed PHEMAG consisted of varying concentrations of HEMA is shown in Figure 4 was established in terms of change in absorbance per unit length cuvette at $575 \mathrm{~nm}$ wavelength against the absorbed dose respectively in relation formulated by Abdel-Fatteh [18]. Equation (1) was used as followed: 


\section{Nur Sha'adah et al: EVALUATION OF DOSE SENSITIVITY RESPONSE VIA OPTICAL CHARACTERISTICS FOR CRESOL RED-DYED POLYHYDROXYETHYLMETHACRYLATE GEL (PHEMAG)}

$$
\Delta A=\left|A_{o}-A_{i}\right|
$$

where $A_{o}$ is the absorbance of the unirradiated and $A_{i}$ refer for the absorbance of irradiated cresol red-dyed PHEMAG.

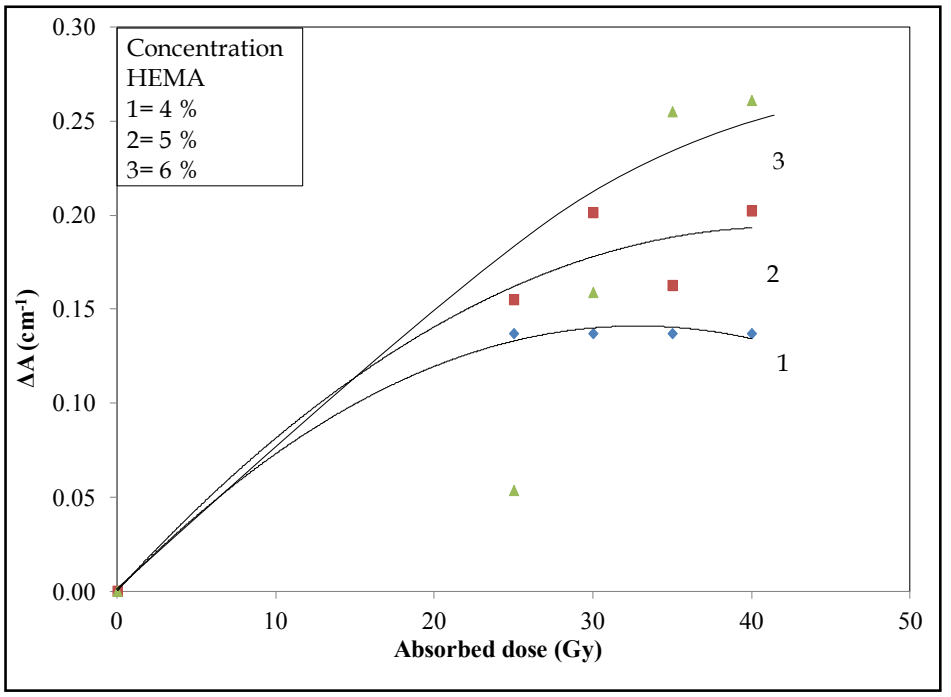

Figure 4. The change in absorbance, $\Delta \mathrm{A}$ as a function of absorbed dose of cresol red-dyed PHEMAG at $575 \mathrm{~nm}$ with different concentration of monomer

Obviously in Figure 4, the dose response curve of maximum absorbance at $575 \mathrm{~nm}$ shows a minor increament with the increased of the concentration HEMA and absorbed dose. Thus, radiation-induced cresol red-dyed PHEMAG led to the yield of acidic form is due to the water radiolysis which indicate the presence of $\mathrm{H}^{+}$[16], hence more chain polymerization would occur between HEMA and cresol red dye. In addition, maximum absorbance at $575 \mathrm{~nm}$ showed a slightly exponential increment with absorbed dose that is fully parallel to the mathemathically model of the fitting equation as follows:

$$
y=y_{o} e^{-D / D_{o}}
$$

where $\mathrm{y}_{\mathrm{o}}$ is the unirradiated absorbance, $D$ is referred as the absorbed dose and Do is referred as 'sensitivity parameter' that also known as the dose sensitivity which refer to minimum amount of dose required to reduce the fraction of molecules for breaking down the monomer to $37 \%$ of the cresol red-dye PHEMAG. In other words, $37 \%$ of the absorbed dose is required for the consumption of HEMA in order to degrade the chemical bond during the chain polymerization of cresol red-dyed PHEMAG. Fitting equation curve to the concentration of HEMA showing a linear relationship with Do as shown in Figure 5.

Eventually, the lower concentration of HEMA for 4\%,5\% and 6\% of cresol red-dyed PHEMAG would exhibit greater sensitive reaction upon irradiation. As depicted for, $4 \%$ of HEMA is having the lowest sensitivity which is $42.37 \mathrm{~Gy}$, whereas $5 \%$ and $6 \%$ of HEMA having 59.52 Gy and 97.09 Gy respesctively. Thus, the value of Do for $4 \%$ of HEMA exhibited a greater sensitivity in order to consume $37 \%$ of monomer in the propagation of chain polymerization. 


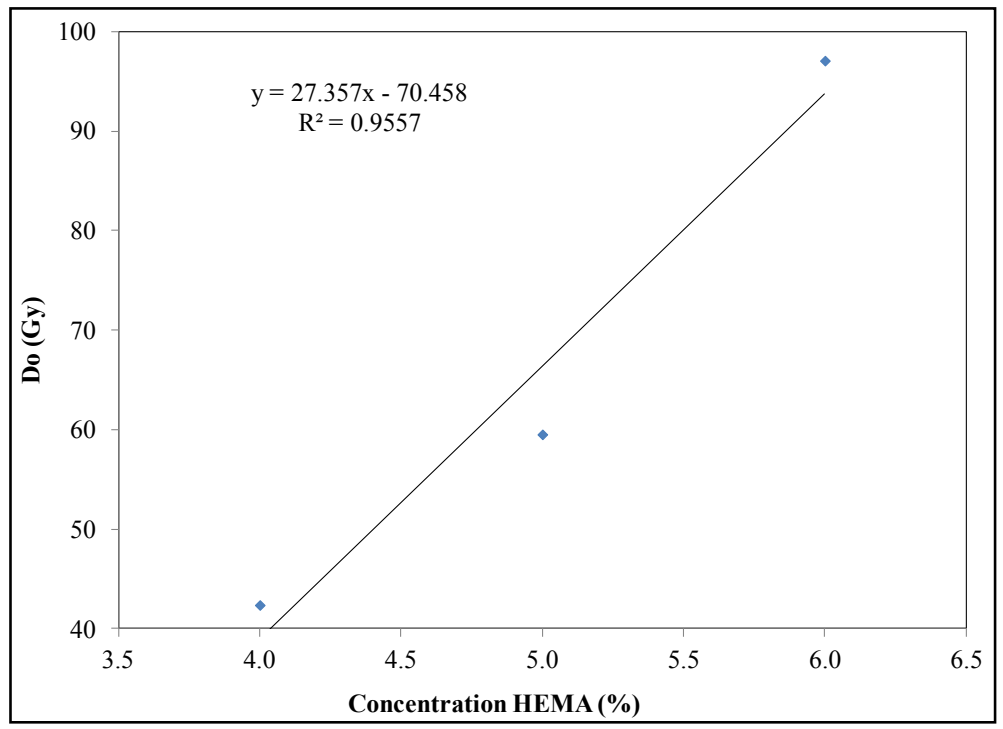

Figure 5. The variation values of the sensitive dose Do as derived at the band $575 \mathrm{~nm}$ as the function of concentration of HEMA for cresol red-dyed PHEMAG

\section{Conclusion}

Cresol red-dyed PHEMAG with different of the monomer concentrations of 2-Hydroxyethyl Methacrylate doped with cresol red dye as polymer gel dosimeter were developed. The optical properties and dosimetric parameter of the Cresol red-dyed PHEMAG were successfully analyzed using UV-VIS spectroscopy based on the variations of absorption spectra. The remarkable of the peak absorbance at $575 \mathrm{~nm}$ illustrate the increasing trend as the increament of absorbed dose shows that the higher radiation dose will induced polymerization. The sensitivity of the Cresol red-dyed PHEMAG showed the significant sensitivity as the monomer concentration decrease. Lastly, the study of the novel polymer gel based on the radiation induced color transition of the dye could be a starting point for further discovery based on the optical properties and structural characterization.

\section{Acknowledgement}

The author would like to acknowledge the financial support by the grant RUi USM 811301and UiTM training budget in finding throughout this work.

\section{References}

1. Schreiner, L. J., Olding, T. and McAuley, K. B. (2010). Polymer gel dosimetry. Journal of Physics: Conference Series, 250(1): 1-5.

2. Mattea, F., Romero, M. R, Vedelago, J., Quiroga, A., Valente, M. and Strumia, M. C. (2015). Molecular structure effects on the post irradiation diffusion in polymer gel dosimeters. Applied Radiation and Isotopes, 100: 101-107.

3. Vandescasteele, J. and De Deene, Y. (2013). Evaluation of radiochromic gel dosimetry and polymer gel dosimetry in a clinical dose verification. Physics in Medicine and Biology, 58(18): 6241-6262.

4. MacDougall, N. D., Miquel, M. E. and Keevil, S. F. (2014). Effects of phantom volume and shape on the accuracy of MRI BANG gel dosimetry using BANG3 ${ }^{\mathrm{TM}}$. The British Journal of Radiology, 81(986): 46-50.

5. Mattea, F., Chacon, D., Vedelago, J., Valente, M. and Strumia, M. C. (2015). Polymer gel dosimeter based on itaconic acid. Applied Radiation and Isotopes, 105: 98-104.

6. Doyan, A. (2009). Dose response and optical properties of dyed poly vinyl alcohol-trichloroacetic acid polymeric blends irradiated with gamma-rays. American Journal of Applied Sciences, 6(12): 2071.

7. Beshir, W. B. (2013). Radiation sensitive indicator based on tetrabromophenol blue dyed poly (vinyl alcohol). Radiation Phycis and Chemistry, 86: 129-135. 


\section{Nur Sha'adah et al: EVALUATION OF DOSE SENSITIVITY RESPONSE VIA OPTICAL CHARACTERISTICS FOR CRESOL RED-DYED POLYHYDROXYETHYLMETHACRYLATE GEL (PHEMAG)}

8. Saion, E., Doyan, A., Zainal Abidin, S., Azmi, Z., Zulkifli, A., Mohd Zaki, A. and Karni, T. (2005). Changes in the optical band gap and absorption edge of gamma-irradiated polymer blends. Journal of Applied Sciences, 5: 1825-1829.

9. Chanda, M. (2000). Advanced polymer chemistry: A problem solving guide. Marcel Dekker: pp. $462-475$.

10. Rozlan, A. A., Jaafar, M. S. and Rahman, A. A. (2011). A study of normoxic polymer gel dosimeter using raman spectroscopy analysis. International Conference on Biomedical Engineering and Technology, 11(2011): 19-23.

11. Ab Razak, N. N. A. N., Rahman, A. A., Kandaiya, S., Mustafa, I. S., Yahaya, N. Z. and Mahmoud, A. A. J. (2015). Accuracy and precision of magat gel as a dosimeter. Material Science Research India, 12(1): 01-08.

12. Vergote, K. (2005). Development of polymer gel dosimetry for applications in intensity-modulated radiotherapy. Department of Radiotherapy and Nuclear Medicine, Faculty of Medicine and Health Sciences, Gent, Belgium: pp. 20-21.

13. MacAuley, K. B. (2006). Fundamentals of polymer gel dosimeters. Journal of Physics: Conference Series, 56(1): 35 .

14. Attix, F. H. (2008). Introduction to radiological physics and radiation dosimetry. John Wiley \& Sons: pp. 3436.

15. Susilawati (2005). Radiation and temperature effects on optical and electrical properties of dyed poly (vinyl alcohol) organic composite containing chlorine. PhD dissertation, Universiti Putra Malaysia.

16. Ebraheem, S., Eid, S. and Kovacs, A. (2002). A new dyed poly (vinyl alcohol) film for high-dose applications. Radiation Physics and Chemistry, 63(3): 807-811.

17. Morris, S. and Williams, A. (2001). Radiotherapy physics and equipment. Churchill Livingstone: pp. 28-30.

18. Abdel-Fattah, A. A., Hegazy, E. S. A. and El-Din, H. E. (2002). Radiation-chemical formation of $\mathrm{HCl}$ in poly (vinyl butyral) films containing chloral hydrate for use in radiation dosimetry. International Journal of Polymeric Materials, 51(9): 851-874. 